\title{
DOEIPC/89652...
}

DOE/PC/89652 - T6

DE92 018210

\section{Innovative Clean Coal Technology}

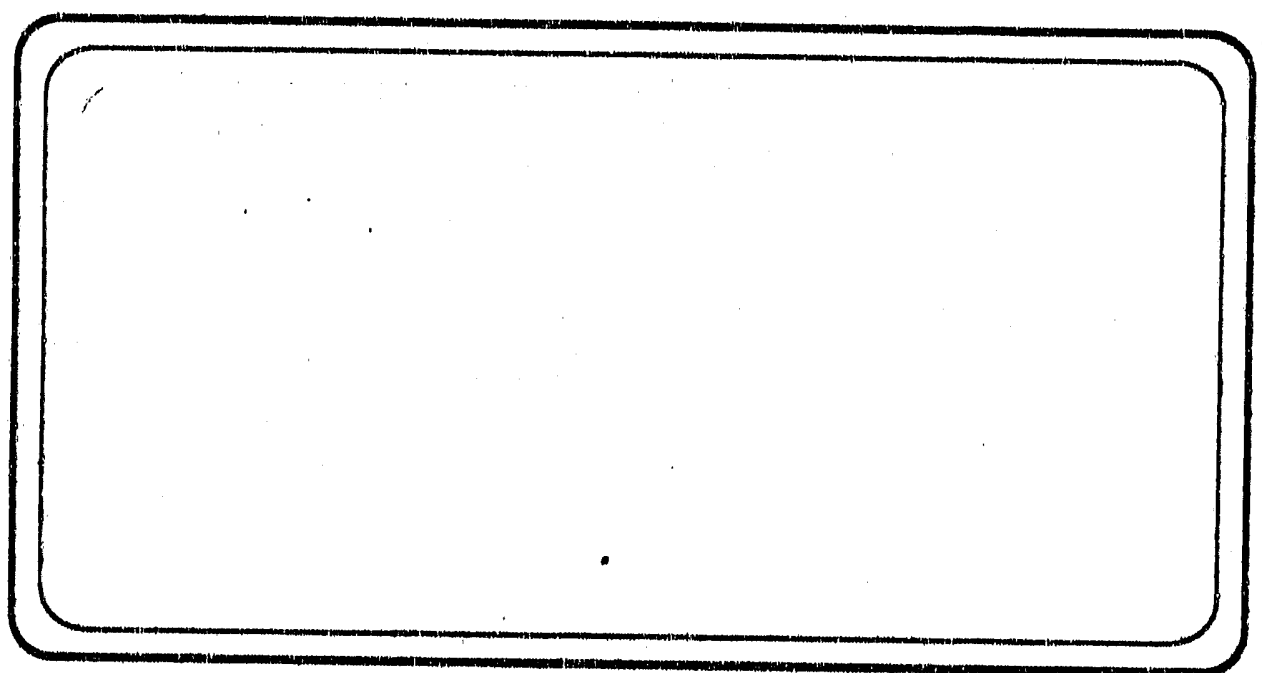

Prepared by:

\section{Southern Company Services, Inc. Birmingham, Alabama}

\begin{abstract}
DISCLAIMER
This report was prepared as an account of work sponsered by an agency of the United States Government. Neither the United States Government nor any agency thereof, nor any of their employoes, makes any' warranty, express or implieci, or assumes any legal liability or responsibility for the accuracy, completeness, or usefulness of any information, apparatus, product, of process disclosed, or represents that its use wowld not infringe privately owned rights. Refer. ence hercin to any specific commercial product, process, or service by trade name, trademark. manufacturer, or otherwise thes not neroessarily constieute or imply its endorsement, recommendation, of favoring by the Unitod States Government or any agency thereol. The views and opinions of authors expressed herein do not necessarily state or reflece those of the United States Government or any agency thereof.
\end{abstract}

\section{Received by OSTT}

JUL 231992 


\title{
DEMONSTRATION OF SELF.CTIVE CATALYTIC \\ REDUCTION (SCR) TECHNOLOGY FOR THE \\ CONTROL OF NITROGEN OXIDE (NOX) EMISSIONS \\ FROM HIGH-SULFUR COAL-FIRED BOILERS

\author{
DOE Contract \\ DE-FC22-90PC89652 \\ SCS Contract \\ C-91-000026
}
Quarterly Report No. 4
For the Period
Aprit-June, 1991

\author{
August 1991 \\ Prepared by: \\ Southern Company Services, Inc. \\ 800 Shades Creek Parkway \\ Birmingham. Alabama 35209
}

Patents Cleared by Chicago on August 20, 1991 
This report. was prepared by Southern Company Services, Inc. pursuant to a cooperative agreement partially funded by the U.S. Department of Energy and neither Southern Company Services, Inc. nor any of its subcontractors nor the U.S. Department of Energy, nor any person acting on behalf of either:

(a) Makes any warranty or representation, express or implied with respect to the accuracy, completeness, or usefulness of the information contained in this report, or that the use of any information, apparatus, method, or process disciosed in this report may not infringe privately-owned rights; or

(b) Assumes any liabilities with respect to the use of, or for damages resulting from the use of, any information, apparatus, method or process disclosed in this report.

Reference herein to any specific commercial product, process, or service by trade name, trademark, manufacturer, or otherwise, does not necessarily constitute or imply its endorsement, recommendation, or favoring by the U.S. Department of Energy. The views and opinion of authors expressed herein do not necessarily state or reflect those of the U.S. Department of Energy. 


\section{Section 1}

SUMMARY

The objective of this project is to demonstrate and evaluate commercially available Selective Catalytic Reduction (SCR) catalysts from U. S., Japanese and European catalyst suppliers on a high-sulfur U. S, coal-fired boiler. SCR is a post-combustion nitrogen oxide (NOX) control technology that involves injecting ammonia into the flue gas generated from coal combustion in an electric utility boiler. The flue gas containing ammonia is then passed through a reactor that contains a specialized catalyst. In the presence of the catalyst, the ammonia reacts with NOx to convert it to nitrogen and water vapor.

Although SCR is widely practiced in Japan and Europe, there are numerous technical uncertainties associated with applying SCR to U. S. coals. These uncertainties include:

(1) potential catalyst deactivation due to poisoning by trace metal species present in U.S. coals that are not present in other fuels.

(2) performance of the technology and effects on the balance-ofplant equipment in the presence of high amounts of SO, and $\mathrm{SO}_{3}$.

(3) performance of a wide variety of SCR catalyst compositions, geometries and methods of manufacture under typical highsulfur coal-fired utility operating conditions.

These uncertainties will be explored by constructing a series of small-scale SCR reactors and simultaneously exposing different SCR catalysts to flue gas derived from the combustion of high sulfur U. S. coal.

The demonsiration will be performed at Gulf Power Company's Plant Crist Unit No. 5 (75 MW capacity) near Pensacola, Florida. The project will be funded by the U. S. Department of Energy (DOE), Southern Company Services, Inc. (SCS on behalf of the entire Southern electric system), and the Electric Power Research Institute (EPRI). SCS is the participant responsible for managing all aspects of this project. 
The project is being conducted in the following three phases:

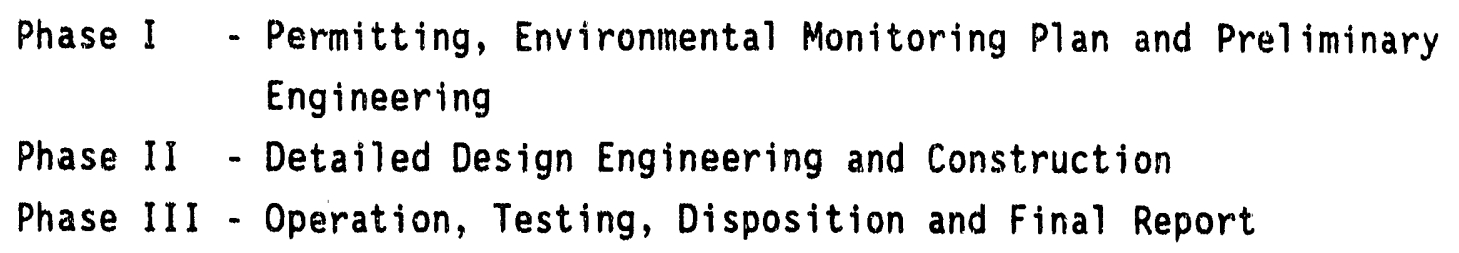

During this reporting period, DynaGen, Inc., a fluid mechanics consulting subcontractor, completed flow model testing on the reactor inlet design configurations. Two additional tests were made to examine the effect of orienting the resistance pipes in a vertical arrangement instead of the previously tested horizontal arrangement. In summary, recommendations were to maintain the horizontal configuration of resistance pipes (also the ammonia injection grid) since the uniform velocity profile results were not as favorable in the vertical arrangement; also, to change to a five cell diffuser with four baffles to match an array of $5 \times 5$ ammonia injection nozzles.

The detailed design engineering phase continued during this reporting period. Vendor bid responses were evaluated and contracts awarded for the rotary and heat pipe air preheaters. Specifications were prepared and released for bids, and vendor responses were evaluated, and contracts awarded for the flue gas and air fans, and for the venturis.

Specifications were completed and released for vendor bids on the distributed control system/data acquisition system, electric distribution systems, and the bypass heat exchangers. Preparation of specifications were begun for the flue gas and air electric heaters and for the cyclones. Detailed design work also began on the ammonia storage system, platforms, control room, and gas sampling system.

SCS submitted a draft list of important testing parameters for laboratory evaluation of SCR catalysts to each of the catalyst suppliers on this project for their review and comments.

DOE and SCS personnel visited two of EPRI's 1-MW-SCR pilot plants. A project status review meeting was held on April 23 with DOE, Gulf Power, and SCS. 
Section 2

INTRODUCTION

The Innovative Clean Coal Technology (ICCT) Program is designed to demonstrate clean coal technologies that are capable of retrofitting or repowering existing facilities to achieve significant reduction in sulfur dioxide $\left(\mathrm{SO}_{2}\right)$ and/or nitrogen oxides (NOX) emissions. The technologies selected for demonstration are capable of being commercialized in the 1990 s and are expected to be more cost effective than current technologies.

This ICCT project is jointly funded by the U.S. Department of Energy, the Electric Power Research Institute (EPRI), and by Southern Company Services (SCS) on behalf of the entire Southern electric system. The project's objective is to demonstrate the selective catalytic reduction (SCR) process that removes nitrogen oxides (NOX) from the flue gas of boilers that burn U.S. high-sulfur coal. The SCR technology involves the catalytic reduction of $\mathrm{NH}_{\text {, }}$ which is injected into the flue gas to react with NOx contained in the flue gas to produce molecular nitrogen $\left(N_{2}\right)$ and water vapor.

A simplified SCR process flow diagram with major equipment is shown in Figure 1. Specifically, hot flue gas leaving the economizer section of the boiler is ducted to the SCR reactor. Prior to entering the reactor, $\mathrm{NH}_{3}$ is injected into the flue gas at a sufficient distance upstream of the reactor to provide for complete mixing of the $\mathrm{NH}_{2}$ and flue gas. The quantity of $\mathrm{NH}$, can be adjusted and it reacts with the $\mathrm{NO}_{\mathrm{x}}$ from the flue gas. The flue gas leaving the catalytic reactor enters the air preheater where it transfers heat to the incoming combustion air. Provisions are made for ash renoval from the bottom of the reactor since some fallout of fly ash is expected. Duct work is also provided to bypass some flue gas around the economizer during periods when the boiler is operating at reduced load. This is done to maintain the temperature of the flue gas entering the catalytic reactor at the proper reaction temperature of about $700^{\circ} \mathrm{F}$. The flue gas leaving the air preheater goes to the electrostatic precipitator (ESP) where fly ash is removed. The ESP is part of the existing plant and is generally unaffected by the SCR system except as higher SO, content affects the electrical resistivity of the fly ash or if NH.HSO, co-precipitates with the fly ash.

The SCR technology is in commercial use in Japan and western Europe on gas, 


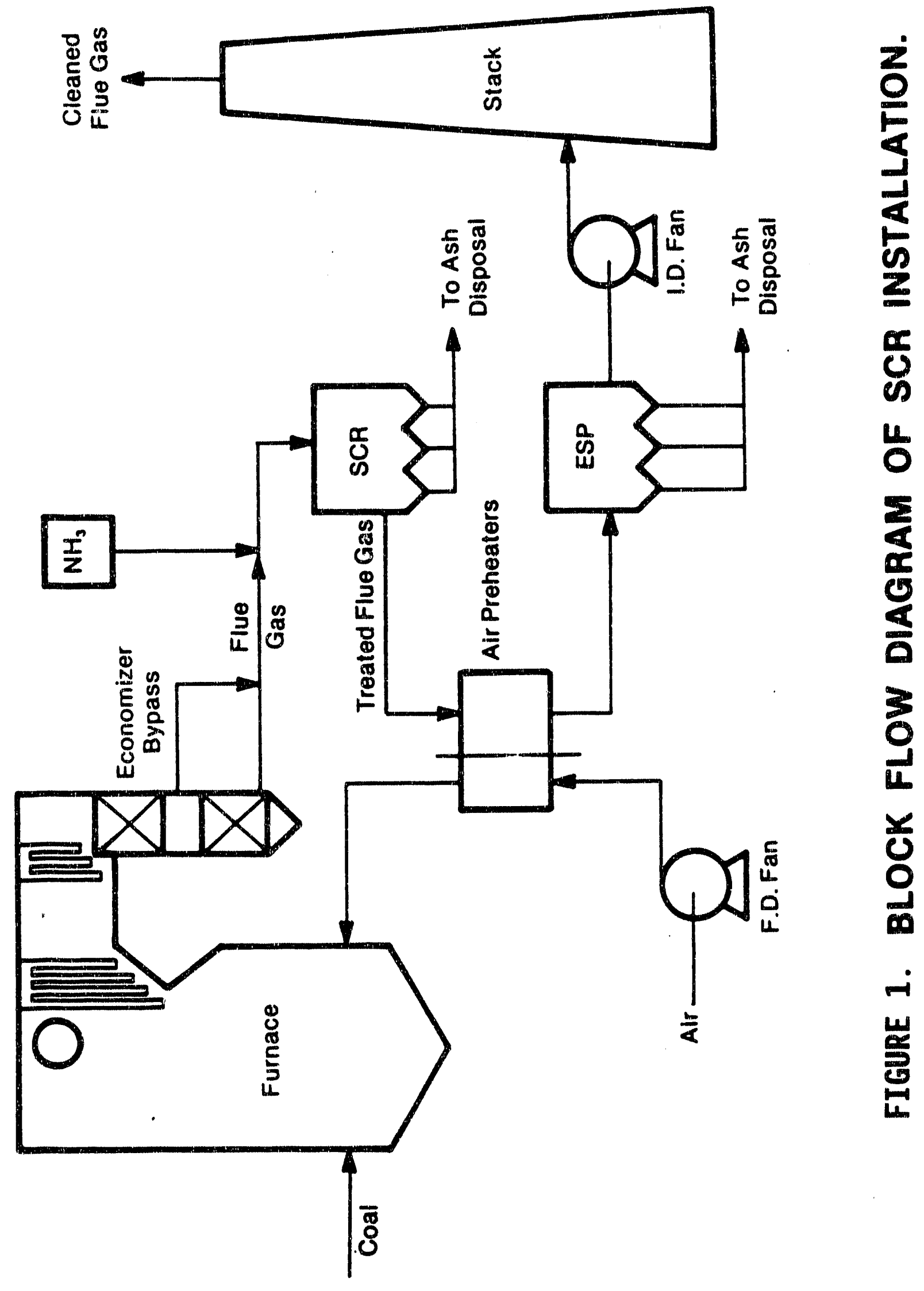


0i1, and on low-sulfur, coal-fired power plants. The first utility applications of SCR catalyst technology started in Japan in 1977 for $0 i 1$ - and gas-fired boilers and subsequentily in 1979 for coal-fired boilers. As of 1986, ninety utility boilers in Japan had been equipped with SCR catalyst technology including twenty-two coal-fired boilers. These coal-fired boilers represent a combined capacity in excess of 6500 MWe and are typically fired with a low-ash, low-sulfur coal.

In addition to Japanese experience, several countries in western Europe (most notably West Germany and Austria) have passed stringent NO, emission regulations that have all but mandated the installation of SCR. Prior to commercial SCR installations in West Germany, utility companies demonstrated several types of SCR facilities in prototype demonstration programs similar to this ICCT project. Over 50 SCR pilot plants were built and operated in western Europe. These pilot plants ranged from 19 to 6200 SCFM and provided the data base that led to commercialization of the SCR technology in western Europe.

Previously completed U.S. work with the SCR process on utility boilers consists of three projects which were carried out in the late 1970s and early 1980s. One of these was carried out on a natural gas fired boiler by Southern California Edison. Another project consisted of a pilot test conducted for the EPA at Georgia Power's Plant Mitchel1. This pilot plant treated a 1000 ACFM (0.5 MWe) slip stream of flue gas resulting from the combustion of lowto medium-sulfur coal. A third pilot-scale project, carried out at the Public Service Company of Colorado's Arapaho Station treated a 5000 ACFM (2.5 MWe) slip stream of flue gas resulting from the combustion of U.S. low-sulfur coal.

Although SCR is widely practiced in Japan and Europe, there are numerous technical uncertainties associated with applying SCR to U.S. coals. These uncertainties include:

(1) potential catalyst deactivation due to poisoning by trace metal species present in U.S. coals that are not present in other fuels. 
(2) performance of the technology and effects on the balance-of-plant equipment in the presence of high amounts of $\mathrm{SO}_{2}$ and $\mathrm{SO}_{3}$. performance of a wide variety of SCR catalyst compositions, geometries and methods of manufacture under typical high-sulfur coal-fired utility operating conditions.

These uncertainties will be exp?ored by constructing a series of small-scale SCR reactors and simultaneousily exposing different SCR catalysts to flue gas derived from the combustion of high sulfur U.S. coal.

The first uncertainty above will be handled by evaluating SCR catalyst performance for two years under realistic operating conditions found in U.S. pulverized coal utility boilers. The deactivation rates for the catalysts exposed to flue gas from high sulfur U.S. coal will be documented to determine accurate catalyst life, and thus, accurate process economics.

The second uncertainty above will be explored by performing parametric testing and through the installation/operation of air preheaters downstream of the larger reactors. During parametric testing, operating conditions will be adjusted above and below design values to observe deNOx performance and ammonia slip as functions of the change in operating conditions. Air preheater performance will be observed to evaluate effects from SCR operation upon heat transfer, and therefore, upon boiler efficiency.

The third uncertainty is being handled by using honeycomb- and plate-type SCR catalysts from U.S., Japan and Europe of various commercial composition. Results from the tests with these catalysts will expand our knowledge of performance on a variety of SCR catalysts under U.S. utility operating conditions with high-sulfur coal.

The intent of this project is to demonstrate commercial catalyst performance, proper operating conditions, and catalyst life for the SCR process. This project will also demonstrate the technical and economic viability of SCR while reducing $\mathrm{NO}_{\mathrm{x}}$ emissions by at least $80 \%$.

The project will be conducted at Gulf Power Company's Plant Crist Unit 5, a commercially operating 75 MW unit, located in Pensacola, Florida, on U. S. coals with a sulfur content near $3.0 \%$. Unit 5 is a tangentially-fired, dry 
bottom boiler, with a hot and cold side ESPS for particulate control. The SCR process to be used in this demonstration will be designed to treat a slipstream of flue gas and will feature multiple reactors installed in parallel. With all reactors in operation, the maximum amount of combustion flue gas that can be treated is 17,400 standard cubic feet per minute (scfm) which is roughly equivalent to $8.7 \mathrm{MWe}$.

The proposed SCS facility is a slip-stream SCR test facility consisting of three 2.5 MWe (5000SCFM) SCR reactors and six 0.20 MWe (400SCFM) reactors that will operate in parallel for side-by-side comparisons of conmercially available SCR catalyst technologies obtained from vendors throughout the world. Figure 2 presents a simplified process flow diagram for the proposed facility. The large (2.5 MWe) SCR reactors will contain commercially available SCR catalysts as offered by SCR catalyst suppliers. These reactors will be coupled with small-scale air preheaters to evaluate th? long-term effects of SCR reaction chemistry on air preheater deposit formation and the deposits' effects on air preheater. The small reactors will be used to test additional commercially available catalysts. This demonstration facility size will be adequate to develop performance data to evaluate SCR capabilities and costs that are applicable to boilers using high-sulfur U.S. coals.

The demonstration project is organized into three phases: (1) Phase I Permitting, Environmental Monitoring Plan and Preliminary Engineering; (2) Phase II - Detail Design Engineering and Construction; and (3) Phase III Operation, Testing, Disposition, and Final Report. The cooperative agreement was signed June 14, 1990, and the project completion date is now projected to be in the second quarter of 1995. The total estimated project costs are $\$ 15,574,355$. The co-funders are $\operatorname{SC}(\$ 6,049,017)$, DOE $(\$ 7,525,338)$, and EPRI $(\$ 2,000,000)$. 


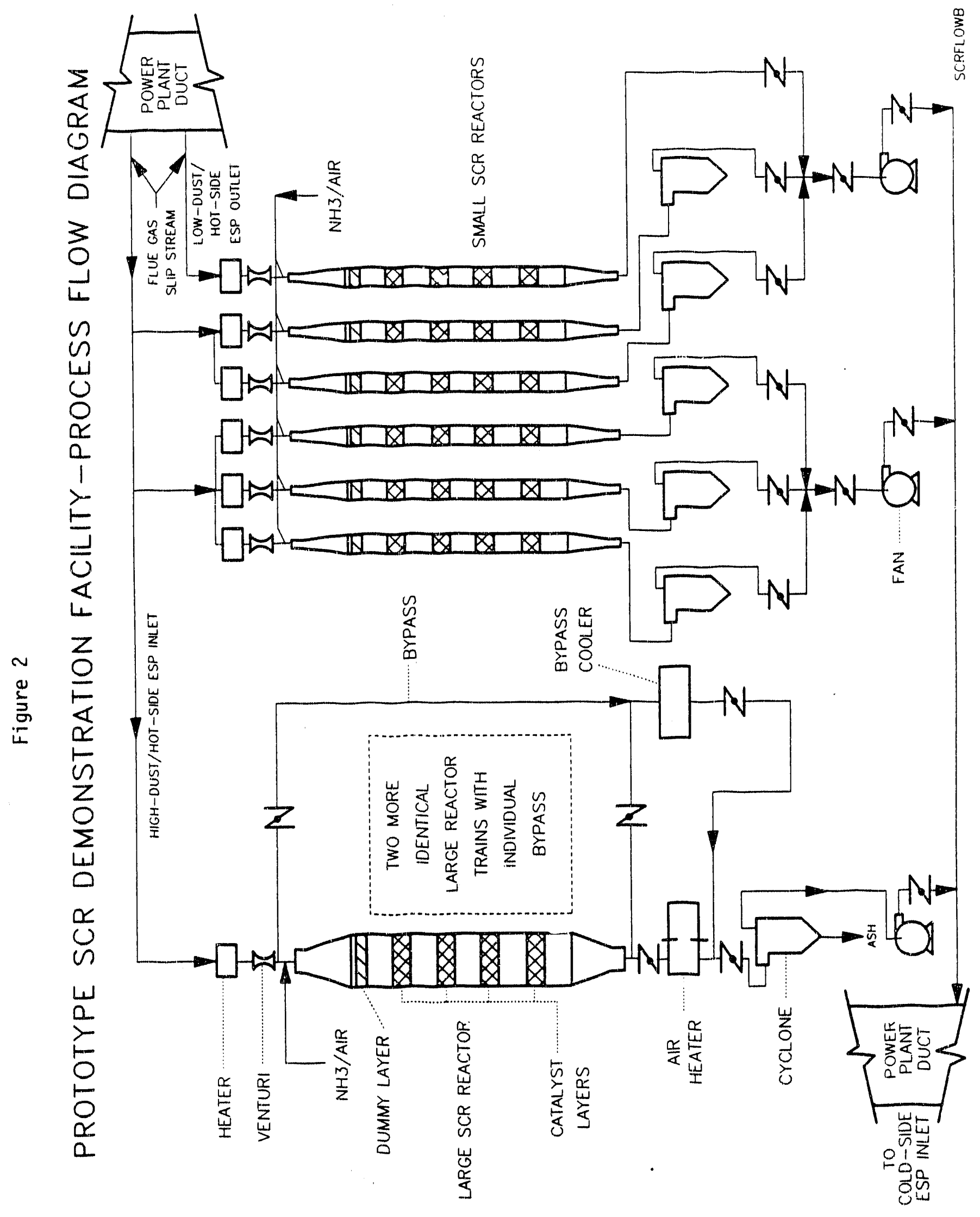


Section 3

PROJECT DESCRIPTION

Within the three phases of the project, the following tasks will be conducted to effectively demonstrate the SCR process:

Phase I - Permitting, Environmental Monitoring Plan and Preliminary Engineering

Task 1.1.1 - Prototype Plant Permitting Activities

Task 1.1.2 - Develop Environmental Monitoring Program

Task 1.1.3 - Preliminary Engineering

Task 1.1.4 - Engineering and Construction Contracts Scope Development

Task 1.1.5 - Project Management and Reporting

Phase II - Detail Design Engineering and Construction

Task 1.2.1 - Detailed Design Engineering

Task 1.2.2 - Construction

Task 1.2.3 - Operation Staff Training

Task 1.2.4 - Planning for Detailed Testing

Task 1.2.5 - Start-Up/Shakedown

Task 1.2.6 - Project Management and Repurting

Phase III - Operations, Testing, Disposition and Final Report

Task 1.3.1 - SCR Demonstration Facility Operations and Maintenance

Task 1.3.2 - Process Evaluation

Task 1.3.3 - Enyironmental Data Management and Reporting

Task 1.3.4 - Economic Evaluation

Task 1.3.5 - Dismantling/Disposition

Task 1.3.6 - Project Management and Reporting 
Section 4

PROJECT STATUS

Progress during April - June, 1991, is summarized below for each of the ongoing tasks in the Scope of Nork.

PHASE I - PERMITTING, ENVIRONMENTAL MONITORING PLAN AND PRELIMINAR'Y ENGINEERING

\section{Task 1.1.2 - Develop Environmental Monitoring Program}

Radian and SCS are addressing the issues previously raised by DOE's comments on the Environmental Monitoring Plan (EMP) in order to finalize the EMP.

\section{Task 1.1.3 - Preliminary ingineering}

During this reporting period, DynaGen, Inc., a fluid mechanics consulting subcontractor, provided videotape highlights from the previously completed flow model testing on the reactor inlet design configurations. Two additional tests were performed using reactor iniet model design number 1 , the design previousiy selected for achieving the best results, to examine the effect of orienting the resistance pipes in a vertical arrangement instes. 1 of the previously tested horizontal arrangement. The unfiorm velocity profile results were not as favorable for the vertical arrangement of the resistance pipes (also serving as the ammonia injection grid) as those previously achieved with the horizontal configuration of piping. In addition to the recommendation to maintain the horizontal arrangement of resistance pipes, it was suggested to increase the number of baffies in the diffuser section of the reactor inlet ducting. The previous testing was done with three baffles, giving a four cell diffuser. The diffuser will be changed to four baffles/five cells to better match an array of $5 \times 5$ ammonia injection nozzles. The results of all the the reactor inlet model testing were summarized in a final report from DynaGen, the majority of which is similar to that given in a preliminary report attached to the previous quarterly progress report. Attached in Appendix $A$ of this report are highlights from the finai report on the above-mentioned additional testing and overall summary of results and conclusions. 
The SCR process Conceptual Design Data Book was essentially completed and assembled, based on preliminary engineering design, and is being prepared for printing.

\section{Task 1.1.4 - Engineering and Construction Contracts Scope Development}

Gulf Power riviewed and gave comments on proposed construction contract scope packages sulmitted previously by SC.S. A meeting was scheduled for July between Gulf Power and SCS to further define procurement and construction procadures and responsibilities, and to begin to identify budget responsiblity between SCS Engineering and Gulf Power Construction for individual base-line cost estimate items.

PHASE II - DETAIL DESIGN ENGINEERING AND CONSTFUCTION

\section{Task 1.2.1 - Eetailed Design Engineering}

The detailed design engineering phase continued during 0.3 reportion period.

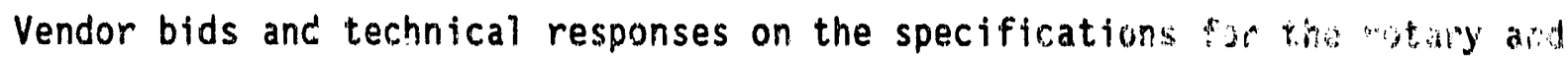
heat pipe air preheaters were evaluated and contracts wt Preheater Inc. Some of the major technical specifications for in air preheaters are listed in Appendix $B$.

Flue gas/air fan specifications were developed and released for bid. 4ator

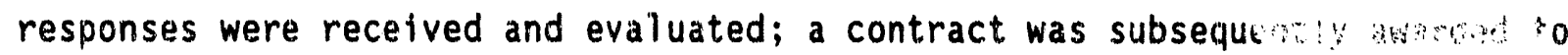
Howden Sirroco. Some of the major technical specifications for ine os and air fans are shown in Appendix $C$. Specification preparation receipt/evaluation of vendor responses were also completed for the $3: 10 \mathrm{~m}$ venturis. The contract was awarded to Flow-lin Corporation.

Specifications were completed and released for vendor bids on the distibutititions control system/data acquisition system, electric distribution systems, ant the bypass heat exchangers. Preparation of specifications were begun for the flute gas and air electric heaters and for the cyclones. Detailed design work began on the ammonia storage system, platforms, control room, and gas sampling system.

SCS prepared a draft list of important testing parameters for laboratory 
evaluation of SCR catalysts. This list was submitted to each of the catalyst suppliers on this project with a request for their comments and recommendations. Some responses were received during this reporting period and the compilation and comparison of responses is underway. Remaining responses are expected early in the next quarter. A copy of the list of laboratory testing parameters sent to each vendor to review is attached in Appendix 0 .

\section{Task 1.2.6 - Project Management and Reporting}

Weekly coordination meetings were heid with Design Engineering. The MIS, developed for tracking overall budget and schedule information, was used to monitor budget and schedule and to heip fulfill DOE reporting requirements. Monthly progress reports were submitted to DOE. A brief status progress summary was prepared and released to each of the catalyst suppiiers.

DOE and SCS personnel visited two of EPRI's 1-MW SCR pilot plants: a hot-side system at TVA's Shawnee Steam Plant near Paducah, Kentucky, and a cold-side system at NYSEG's Somerset Station. A project status review meeting was held on April 23 with DOE, Gulf Power, and SCS personnel in attendance. 
Section 5

PLANNED ACTIVITIES

During the July - September, 1991 quarter, the following activities are planned:

- Issue the draft Design Data Book to DOE for review.

- Complete the following portions of Phase II, detailed engineering design:

1. Complete evaluations of vendor bid responses and award contracts for distributed control system, bypass heat exchanger, and electric distribution system.

2. Develop specifications, issue inquiries for vendor bids, complete evaluations of vendor bid packages, and award contract for cyclones, flue gas and air electric heaters, and the ammonia handling system.

3. Develop specifications and issue inquiries for vendor bids on the gas sampling system.

4. Develop specifications and investigate leasing arrangement for the air compressors.

5. Complete specifications for the design of the reactor vessels in preparation for issueing to catalyst vendors for review.

- Hold design review meeting with DOE/EPRI and status review meeting with Gulf Power. 


\section{APPENDIX A}

Additional Results and Conclusions from DynaGen

for Reactor Inlet Model Designs 


\subsection{Test of Modified Reactor Inlet Duct Geometry With a Four Passage Diffuser}

The velocity profiles for the base duct geometry show that the velocity is to in the center region of the duct and too low around the sides for traverse locati L3, and L4. The biggest problem and greatest profile non-uniformity is causeu transition from a 1' circle to a 1' square. Peak velocities at the outlet of the gradua. diffuser (Location 2, Figure 3.5 data) show velocities still greater than $50 \mathrm{fps}$, more than three times what is desired at the core inlet and outlet. The only practical way to reduce these velocities and distribute the flow more uniformly in the short duct path of the model design no. 1 is to use a resistance device that will have the following characteristics:

1. reasonable pressure loss while creating the required velocity profile improvement at the core;

2. simple and low cost design; 

3. resistance to erosion; and
4. could be part of the ammonia injection system requirements.

The type of resistance that meets these requirements the best is a set of pipes installed across the duct cross-section at a location where the velocity profile is poor and must be improved downstream. The location selected was immediately at the outlet of the circle to square transition which also corresponds to a possible ammonia injection cross-section.

Table 3-1 summarizes data for four tests with three different pipe resistances and shows what figures present the detailed geometry and detailed velocity profiles. The use of a pipe resistance has progressively increased the diffuser outlet (Location 2) uniformity from $16.7 \%$ of data within $\pm 10 \%$ for Test 10 and 11 to $87.5 \%$ of data within $\pm 10 \%$ for Test 16 and 17. At the same time, the same values at Location 3 have improved from 41.3\% for Test 11 to $93.8 \%$ for Test 16 and at Location 4 have improved from $81.9 \%$ for Test 11 to $95.5 \%$ for Test 17 . This is probably as close as we can hope to get to the objective with a two foot dummy core. Further improvement can be obtained by increasing from 2' to 3 ' or more of dummy core length and corresponding resistance.

The difference between Tests 16 and 17 geometries is that Test 16 has the 12" model spacer in place between the elbow and the core whereas Test 17 does not have the spacer in place. When the spacer is removed, the uniformity at Location 3 (core inlet) gets a little worse but the uniformity at Location 4 (core outlet) actually gets a little better.

For these two tests (16 and 17) at Location 3 (core inlet), the velocities below 90\% of average are near the duct sides that correspond to the inner and outer walls of the $90^{\circ}$ duct elbow. Only Test 17 without the 12 " spacer shows low velocities near the inner bend because the traverse station 3 is 12 " closer to the vanes in the elbow. These are the values that make the uniformity worse for Test 17 at Location 3 . The high velocities occur mostly near one side wall. For Location 4 (core outlet), the low velocities occur near the outside of the elbow and the high velocities occur near the same side wall as Location 3.

\subsection{Test of Modified Reactor Inlet Duct Geometry With a Five Passage Diffuser}

The diffuser for the model design number 1 for the large reactor inlet was changed to have five cells and the five pipes were oriented vertically to be parallel to the four diffuser baffle plates. The geometry of the diffuser and the two pipe resistances tested are shown on Figure 3-27. The Test 23 pipes are equally spaced (half space to walls) like Test 14 . The Test 24 pipes are unequally spaced (more than half space to walls) like Tests 16 and 17 . For Tests 14,16 , and 17, the pipes were oriented horizontally which is perpendicular to the diffuser baffle plates. This latter pipe arrangement is more desirable because the wakes and jets of flow from the pipes are cut into small pieces by the perpendicular diffuser baffle plates and cells. When the pipes are parallel to the diffuser 
baffles and cells, whole jet and wake regions from the pipes are swallowed by the diffuser cells with less opportunity for break-up and mixing. 3-1.

Velocity traverses were taken at the following locations as specified on Figure
Location 2
Location 3
Diffuser Outlet
Location 4
Dummy Core Inlet
Dummy Core Outlet

The uniformity values for the three traverses for each of the two tests presented on Figures 3-28 through 3-39 are summarized on Table 3-2 along with the previous Tests 14 and 17 for comparison. Table 3-2 also shows which data figures go with which test number and traverse location.

Test 23 with uniform pipe spacing is comparable in pipe resistance geometry to Test 14. The velocity uniformity at Locations 2 and 3 for Test 23 is better than Test 14 while Location 4 results are slightly worse for Test 23 . Test 23 compared with Test 17, the previous best uniformity, is not as good a uniformity at all three traverse locations. The velocity profile at Location 2 for Test 23 exhibits more up and down alternate variation in the row average readings on Figure 3-28 than for previous Tests 14 and 17 which may be related to the pipe orientation change. Also, since the lowest row average values occurred for the top and bottom rows on Figure 3-28 which corresponds to the outside slanted walls of the outer diffuser cells, the decision was made to try the nonuniform spacing of pipes from the best previous Test 17 but rotated $90^{\circ}$.

Test 24 with the non-uniform pipe resistance spacing achieved the following in comparison to Test 23:

\section{Improvements}

- The top and bottom row average velocity values were increased and velocities in the center of the duct were decreased.

- The velocity uniformity values compared to Test 23 were improved significantly at Location 2 but only slightly at Location 4.

- The spread between adjacent row average values for Location 2 decreased in most cases.

\section{Worse Results}

Location 3 uniformity results were worse than Test 23.

In general, the isovelocity patterns for Locations 3 and 4 are quite similar for Tests 23 and 24 but Test 24 is better at the most important Location 4. 
When compared to the best previous Test 17, neither Test 23 nor Test 24 come very close at any of the traverse locations. In fact, at Location 4 , Test 14 also has better velocity uniformity than the results of Tests 23 and 24 . Comparison of Test 17 to Test 24 at Location 4 shows:

\begin{tabular}{|c|c|c|c|}
\hline Test & RMS & $\pm 1-10 \%$ Band & $+1-15 \%$ Band \\
\hline 17 & 0.049 & $95.5 \%$ & $99.0 \%$ \\
\hline 24 & 0.062 & $88.5 \%$ & $97.6 \%$ \\
\hline $\begin{array}{l}\text { Test } 17 \text { is better } \\
\text { than Test } 23 \text { by }\end{array}$ & 0.013 & $7.0 \%$ & $1.4 \%$ \\
\hline
\end{tabular}

\subsection{Pressure Loss Results for Reactor Inlet Model Design No. 1}

Pressure measurements were taken for all of the tests at the four test locations shown on Figure 3-1 and reduced to stagnation pressure loss as described in Section 2.3. These tests showed the following results when scaled to field operating conditions using the field condition in Section 2.4:

1. The reactor core material showed a field stagnation pressure loss of 0.160 inches of water per foot of core material equivalent to 5.57 inlet face velocity heads loss per foot of core length.

2. The $90^{\circ}$ vaned expanding area elbow showed a field stagnation pressure loss of 0.043 inches of water.

3. The duct and pipe resistances between Locations 1 and 2 showed the following field stagnation pressure loss values:

Test deltaP ${ }_{T}$ (inches of water)

$\begin{array}{ll}10,11 & 0.081^{\prime \prime} \\ 12 & 0.219^{\prime \prime} \\ 14 & 0.326^{\prime \prime} \\ 16,17 & 0.331^{\prime \prime} \\ 23 & 0.335^{\prime \prime} \\ 24 & 0.334^{\prime \prime}\end{array}$


VELOCITY UNIFORMITY VALUES FOR TRAVERSE LOCATIONS 2, 3, AND 4 FOR NEW TESTS 23 AND 24 AND PREVIOUS TESTS 14 AND 17

Test Traverse

No. Location

232 (Fig. 3-28, 3-2.9)

3 (Fig. 3-30, 3-31)

4 (Fig. 3-32, 3-33)

242 (Fig. 3-34, 3-35)

3 (Fig. 3-36, 3-37)

4 (Fig. 3-38, 3-39)

$14 \quad 2$

3

4

$17 \quad 2$ (Fig. 3-19)

3 (Fig. 3-23)

4 (Fig. 3-25)

\begin{tabular}{|c|c|c|c|}
\hline RMS & $\begin{array}{c} \pm 10 \% \text { Band } \\
(\%)\end{array}$ & $\begin{array}{c} \pm 15 \% \text { Band } \\
(\%)\end{array}$ & $\begin{array}{r} \pm 25 \% \\
(\%) \\
\end{array}$ \\
\hline 0.093 & 70.8 & 88.5 & 100 \\
\hline 0.078 & 84.4 & 94.8 & 99.0 \\
\hline 0.070 & 86.5 & 96.5 & 99.0 \\
\hline 0.076 & 83.3 & 94.8 & 100 \\
\hline 0.087 & 79.9 & 91.0 & 98.6 \\
\hline 0.062 & 88.5 & 97.6 & 99.3 \\
\hline 0.104 & 61.5 & 85.4 & 97.9 \\
\hline 0.088 & 80.9 & 92.7 & 98.6 \\
\hline 0.062 & 89.9 & 98.6 & 99.7 \\
\hline 0.066 & 87.5 & 97.9 & 100 \\
\hline 0.074 & 86.1 & 95.5 & 99.7 \\
\hline 0.049 & 95.5 & 99.0 & 100 \\
\hline
\end{tabular}


Figure 3-1

MODEL GEOMETRY AND VELOCITY TRAVERSE LOCATIONS FOR REACTOR INLET MODEL DESIGN NO. 1

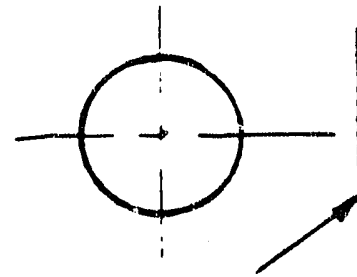
$1 / 2$ " $\times 1 / 2$ " grid flow straightener (Model Scale Factor $=2.0$ )
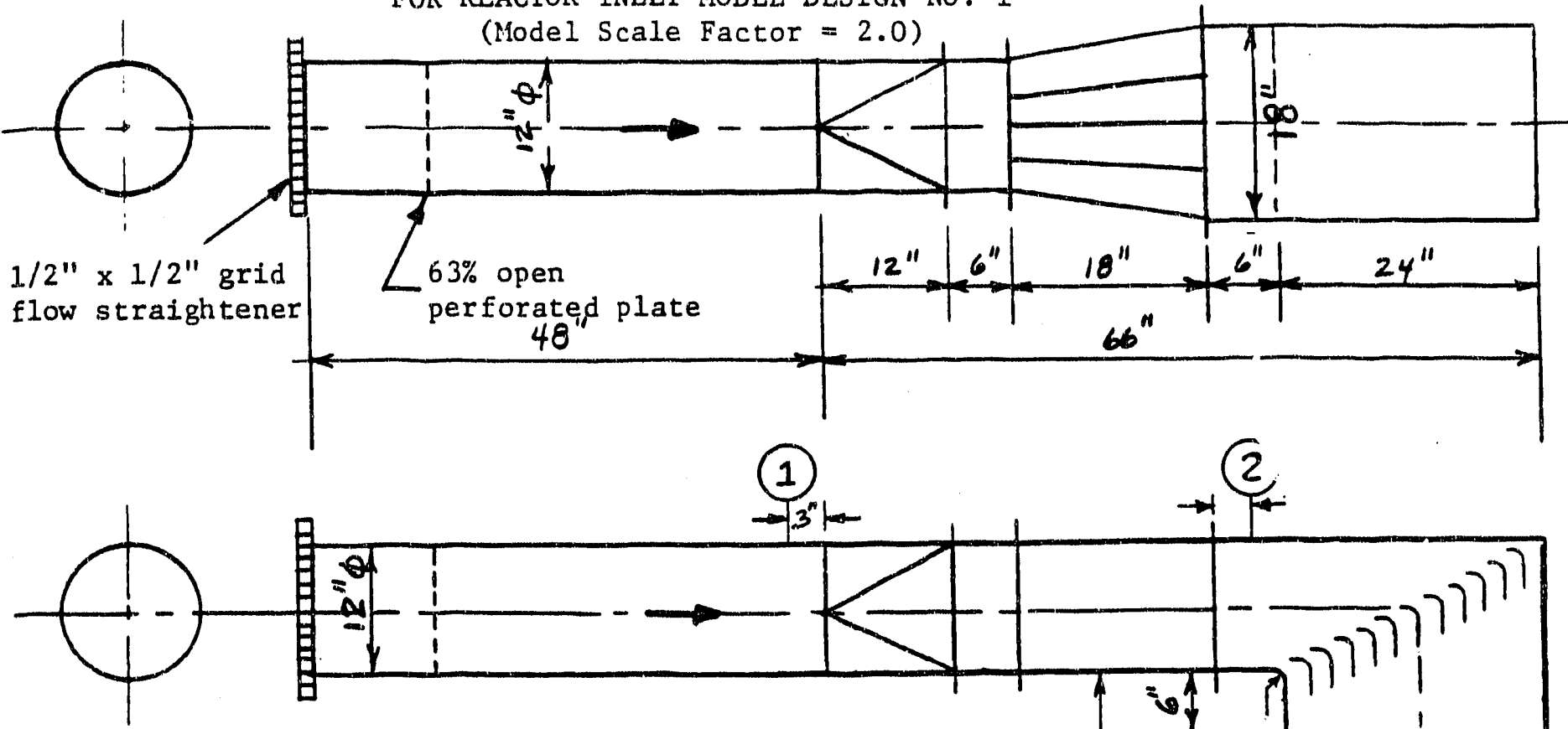

(1)

(2)

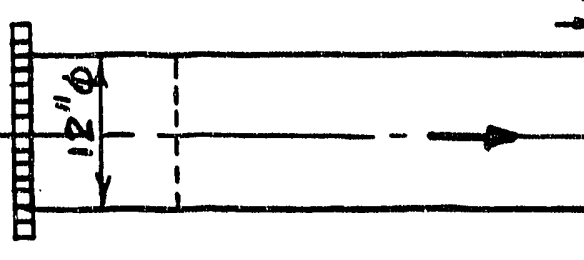

Instrumentation Locations

1. Pitot tube

40 points, 8 radii, 5 points

2. Hot wire anemometer

96 points $(8 \times 12)$

3. Hot wire anemometer 288 points $(12 \times 24)$

4. Hot wire anemometer 288 points $(12 \times 24)$
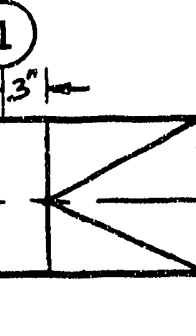

Spacer size varies from $0 "$ to 12 "
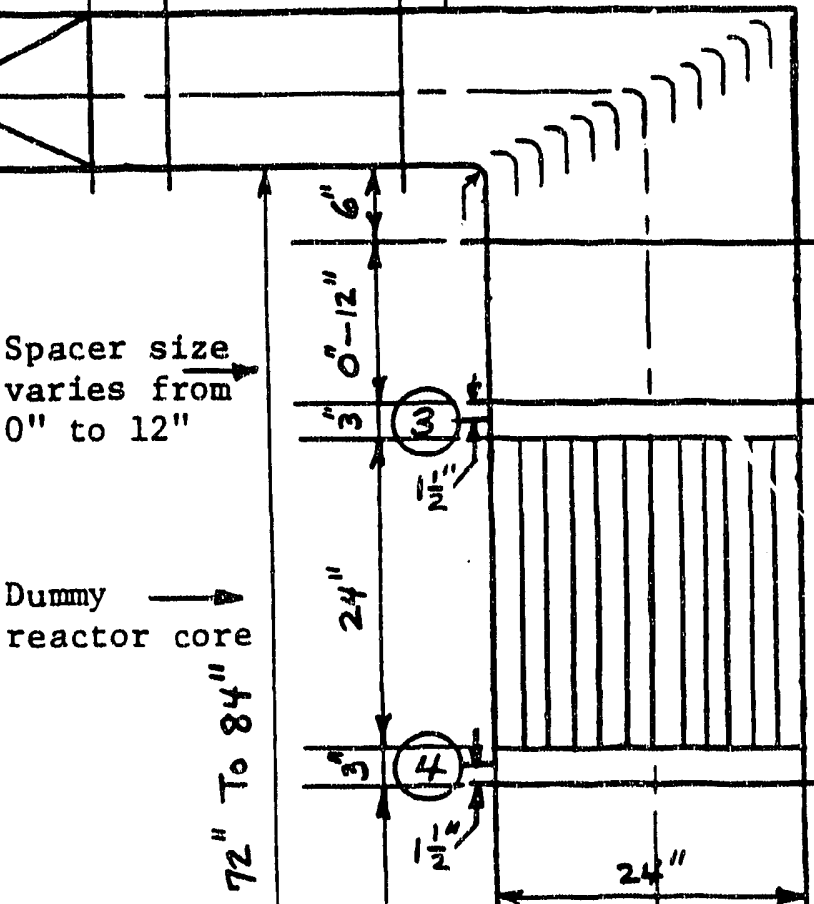

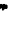
N
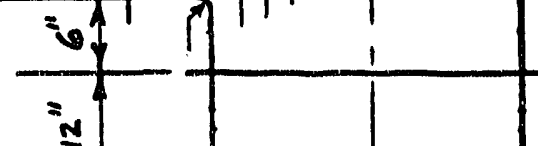
Figure $3-3$

GEOMETRY OF MODEL PIPE RESISTANCES FOR TESTS 12, 14, 16, AND 17

(Model Scale Factor $=2$ )

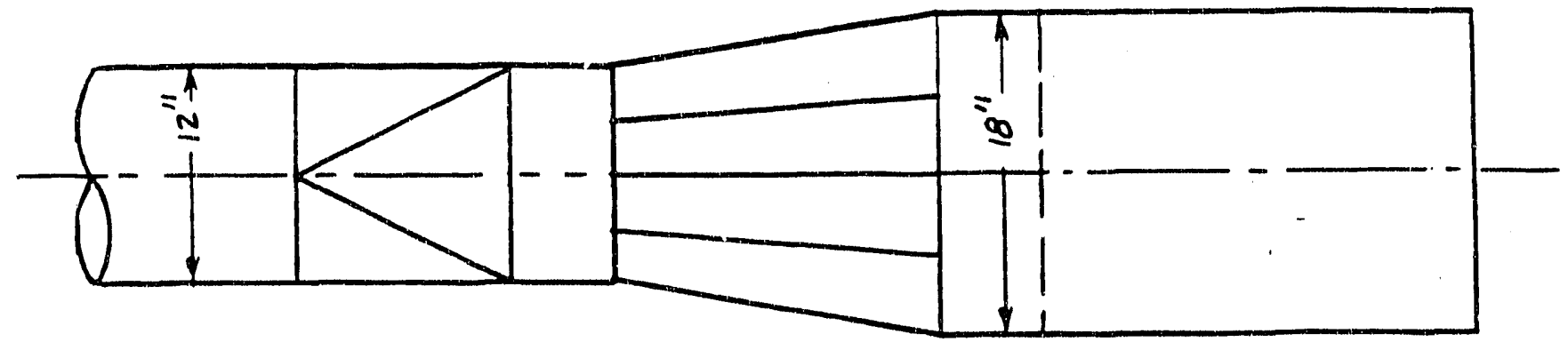

Pipe Resistance for Test 12

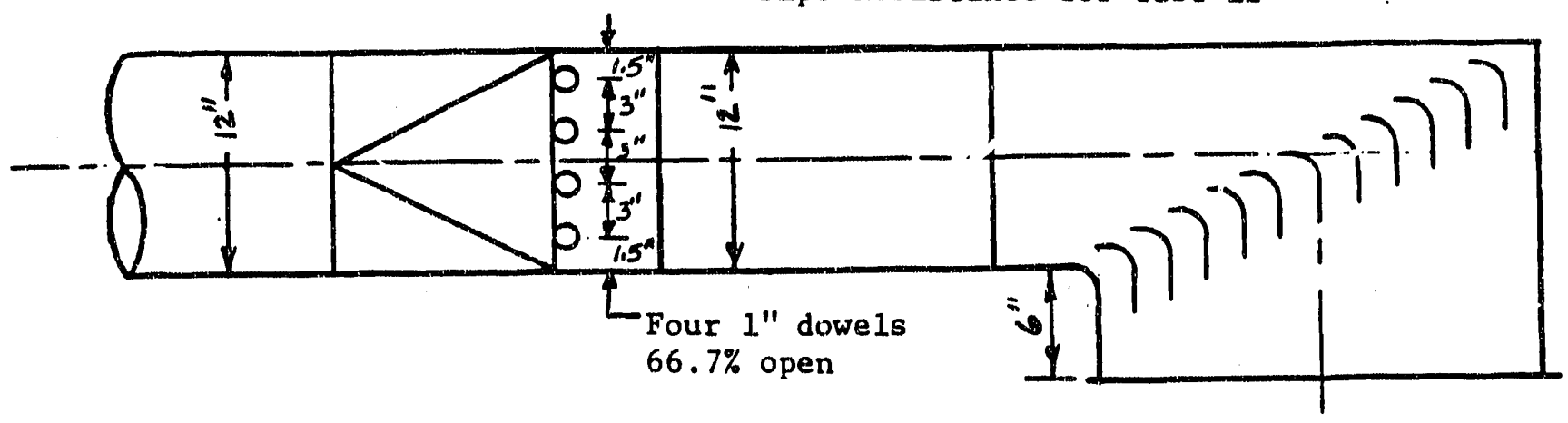

Pipe Resistance for Test 14
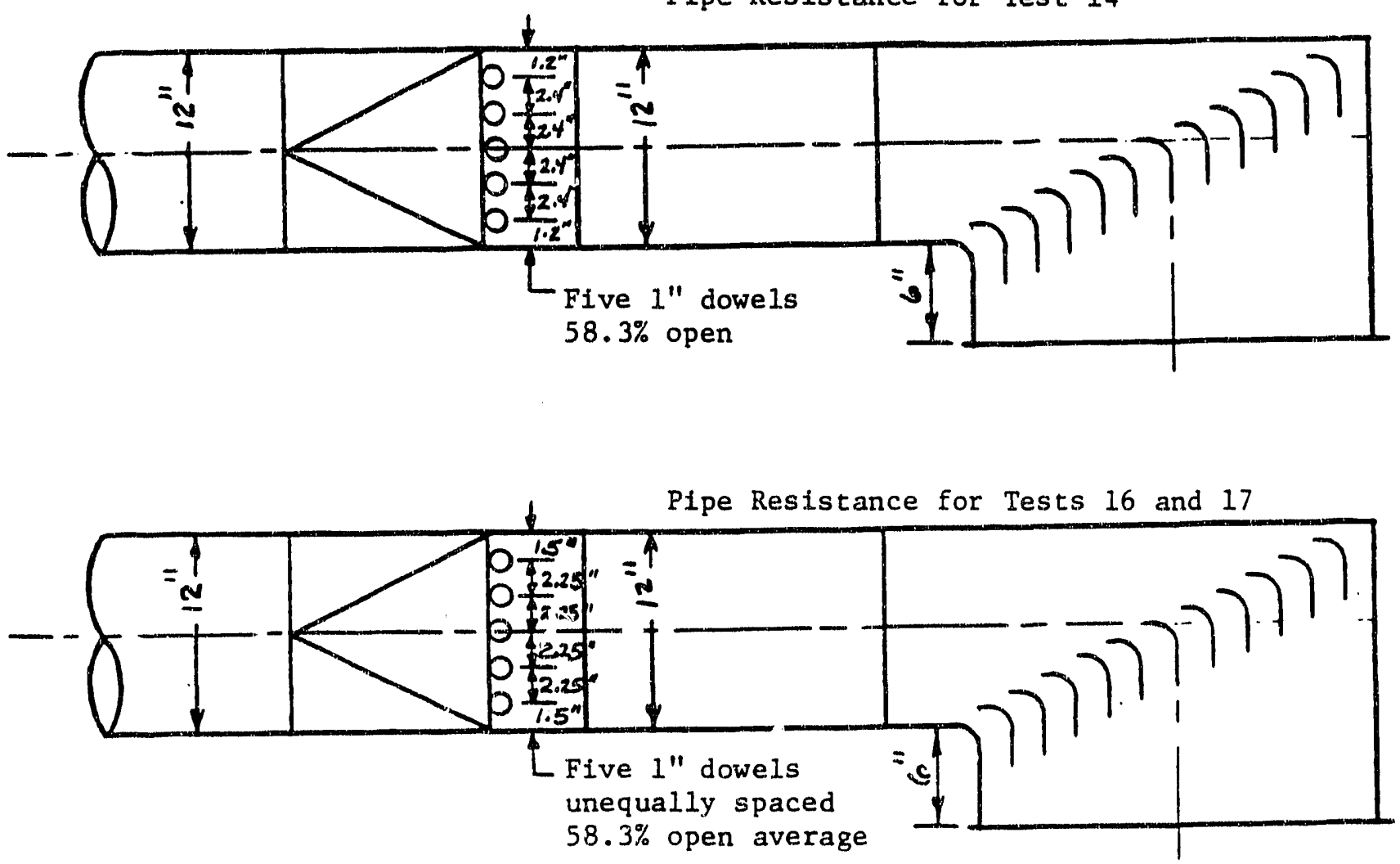


\section{Section 5}

\section{CONCLUSIONS FROM EXPERIMENTAL EVALUATION OF TWO REACTOR INLET MODELS}

\subsection{Model Design No. 1 With Four Passage Difuser}

1. This is the minimum height and length design and is a more practical field unit configuration.

2. The initial base design with elbow vanes and diffuser baffles but no resistance pipes was very poor.

3. Resistance pipes are needed at the outlet of the circle to square transition to improve velocity profile uniformity.

4. The best velocity uniformity results achieved at the core outlet Location 4 (Figure 3-25) for Test 17 were RMS $=0.049,95.5 \%$ of data with $\pm 10 \%$ of average, and $99.0 \%$ of data within $\pm 15 \%$.

5. This velocity uniformity could be improved further by:

a. adding more dummy core length;

b. using unequally spaces vanes; or

c. adding a second resistance at the diffuser outlet or the elbow outlet.

6. The pressure loss is low from Location 1 in the inlet pipe to Location 4 at the core outlet and equal to about 0.69 inches of water at field operating conditions.

7. The pipe resistance can be used as the grid for the ammonia injection nozzles.

8. The use of a $12^{\prime \prime}$ model (24" field) spacer between the elbow outlet and dummy core inlet gives better results above the dummy core but worse results at the dummy core outlet.

\subsection{Model Design No. 2}

1. The length of this design is at a practical minimum but the elevation is about 66 field inches more than design no. 1. 
2. The initial base design with elbow vanes and diffuser baffles but no resistance pipes was better than model design no. 1 without resistance pipes but not as good as the best configuration of model design no. 1 with resistance pipes.

3. Resistance pipes are needed at the outlet of the circle to rectangular transition to improve velocity profille uniformity.

4. The best velocity uniformity results achieved at the core outlet Location 4 (Table $4-1$ ) for Test 21 were RMS $=0.055,91.3 \%$ within $\pm 10 \%$ of average and $99.0 \%$ within $\pm 15 \%$ of average. This is almost as good as model design no. 1.

5. This velocity uniformity could be improved further by:

a. adding more dummy core length; or

b. adding resistance pipes to the outlet of the second diffuser.

6. The pressure loss as compared to model design no. 1 is about 0.28 inches of water more due to higher velocity levels through the pipe resistance.

7. The pipe resistance can be used as the grid for the ammonia injection nozzles.

\subsection{General Conclusions Between Reactor Inlet Model Designs 1 and 2}

1. Model design no. 1 achieves the best velocity uniformity results at the core outlet for the minimu a space, pressure loss and cost although the objective of all data within $\pm 1 \% \%$ of average is not achieved.

2. The pipe resistance at the duct transition outlet should be used as the ammonia injection grid. A grid of 25 nozzles could be used conveniently, five on each of five pipes. The horizontal diffuser should be changed to include five passages rather than four.

3. The size of the resistance elements in field dimensions should be $2.0^{\prime \prime}$ outside diameter. This could be achieved by using a $2.0^{\prime \prime}$ outside diameter tube or by using $1.5^{\prime \prime}$ nominal pipe size that has an outisde diameter of 1.90 inches and putting a thin ( $\left.0.05^{\prime \prime}\right)$ abrasion resistant coating on the outside to reach $2.0^{\prime \prime}$

4. The best way to further improve uniformity would be to add one or two additional feet of dummy core to the two feet of core tested in the model. 


\subsection{Evaluation of Resistance Pipes Installed Parallel to Diffuser Bames (Tests 23 and 24) Rather Than Perpendicular (Tests 14 and 17)}

If the resistance pipes are also goirg to be used as the $\mathrm{NH}_{1}$ nozzle supply pipes, then the non-uniform pipe spacing for Tests 17 and 24 will produce a non-uniform nozzle grid, if the nozzles are mounted on the pipe centerlines. Figure 5-1 shows the nozzle positions on the resistance pipes for Tests 14, 17, 23, and 24 . Tests 14 and 23 have uniform pipe spacing and the 25 nozzles can easily be located at the center of 25 equal areas in the 2' $\times 2$ ' field unit cross-section. However, the non-uniform pipe spacing of Tests 17 and 24 cause offsets from the ideal spacing for all but the center pipe. Offets in the outer most pipes on each side is 0.60 inches.

The nozzles for Test 17 can easily be centered in the diffuser cell passages with the offset occurring along the vertical centerline of each cell passage. This would appear to be much more preferable than the Test 24 artangement where the nozzles are offset from four out of five of the diffuser cell vertical centerlines. It would be possible to position the nozzles away from the pipe centerline with small offset connectors or to angle the nozzles slightly to compensate for their non-uniform spacing. However, this is an added complication that probably is not warranted.

\section{Coliclusions and Recommendations}

1. Test 17 with the non-uniformly spaced resistance pipes perpendicular to the diffuser baffles achieves the most uniform velocity profile results at the dummy core outlet and comes significantly closer to the goal of $100 \%$ of readings within $\pm 10 \%$ of the average velocity than any other test geometry.

2. Although uniform nozzle spacing would be most desirable, the nozzle spacing and location relative to the diffuser baffles for Test 17 is expected to be satisfactory for $\mathrm{NH}_{3}$ mixing. Test 17 nozzle locations are better than Test 24 nozzle k ations.

3. Test 17 geometry (Figures 3-1, 3-2, 3-3) should be changed to a five passage diffuser with four baffles as shown on Figure 3-27 for Tests 23 and 24 to match an array of $5 \times 5$ nozzles for $\mathrm{NH}_{3}$ injection. Test 17 does not include a spacer between the elbow outlet and the dummy core.

4. I do not understand the concern about having the $\mathrm{NH}_{3}$ supply pipes vertical rather than horizontal. If there could be pluggage of these pipes or nozzles, provisions could be made to clean out the pipes and nozzles if a problem does develop. Also, if a certain orientation of the $\mathrm{NH}_{3}$ supply pipes is necessary, the pilot plant is the place to find out. You might consider installing one or more of two pipe resistances and pipe orientations on the five large reactors for evaluation. 


\subsection{Histogram of Velocity Data for Recommended Configuration for Test 17 at the Dummy Core Outlet Location 4}

The histogram of velocity data is presented on Figure 5-2 as Percent of Data Points in Bands that are $2 \%$ of average velocity wide. Any field data that you take can be reduced in the same way and compared against this model data profile. 
Figure 5-1 LOCATION OF PIPES AND NOZZLES FOR TWO RESISTANCE PIPE ORIENTATIONS

$$
\text { FULLSCALE DIMENSIONS }
$$

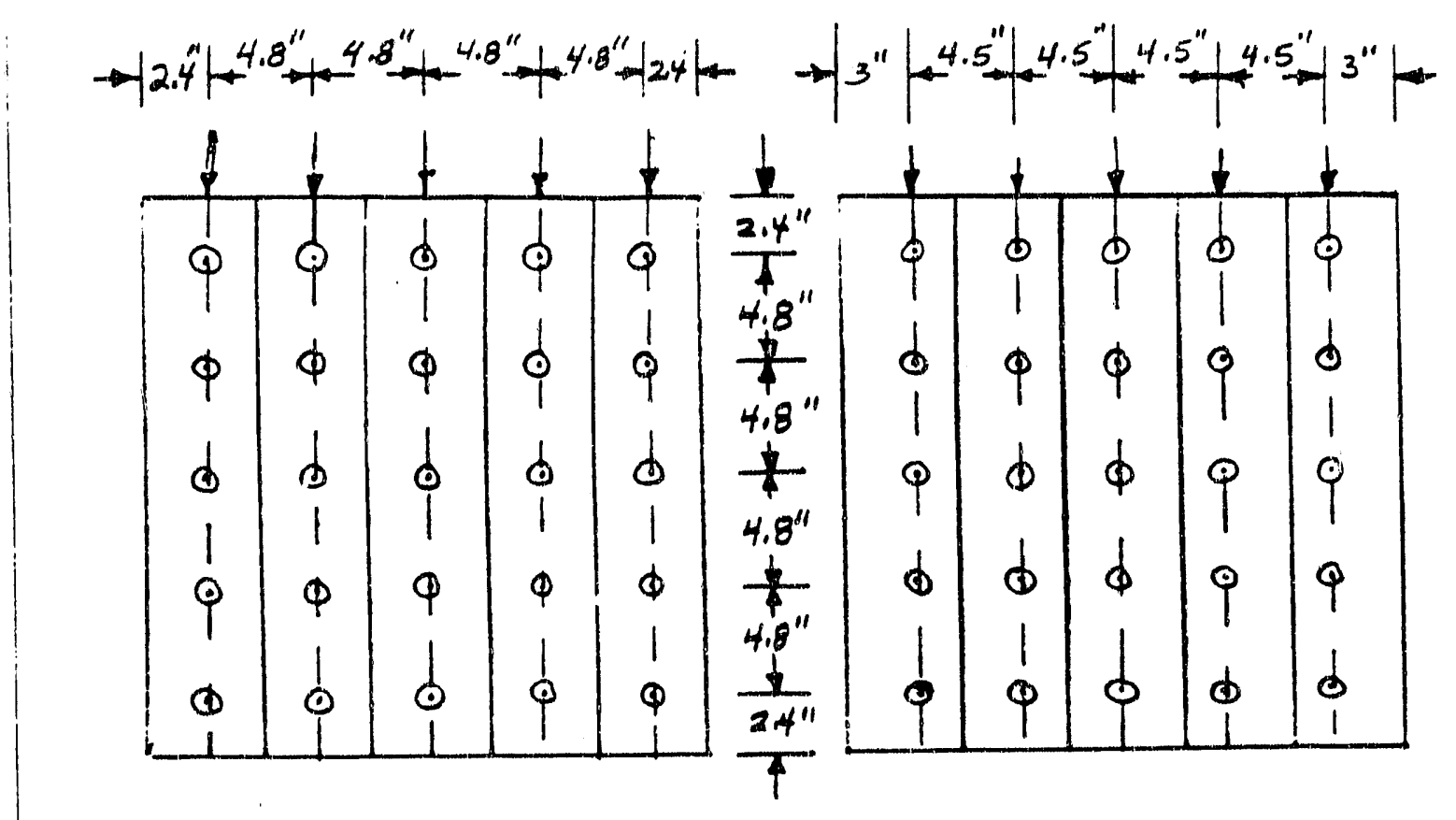

TEST 23

TEST 24

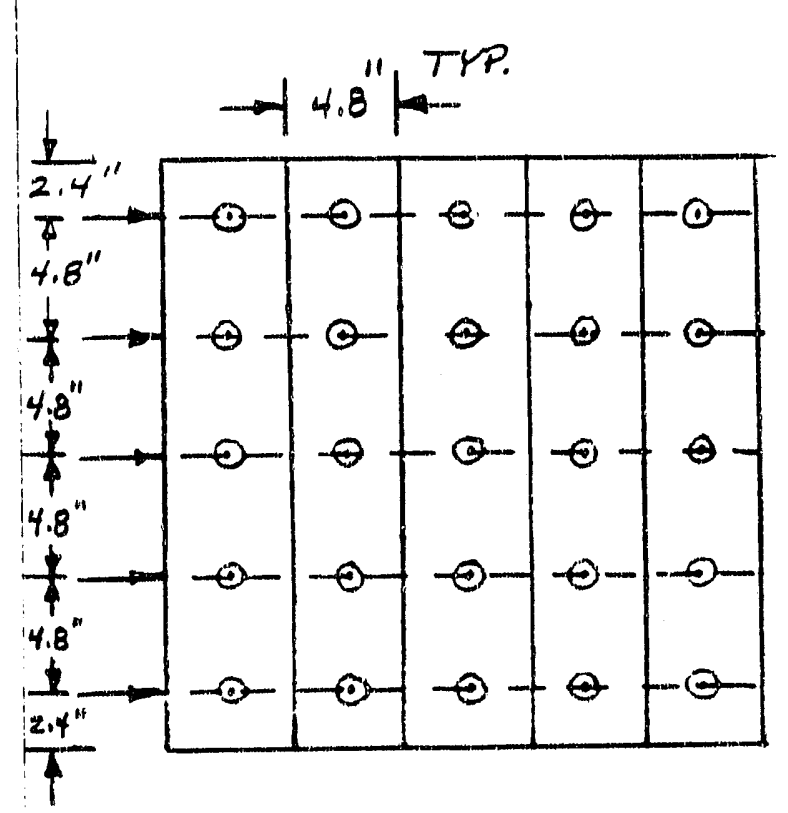

TEST 14

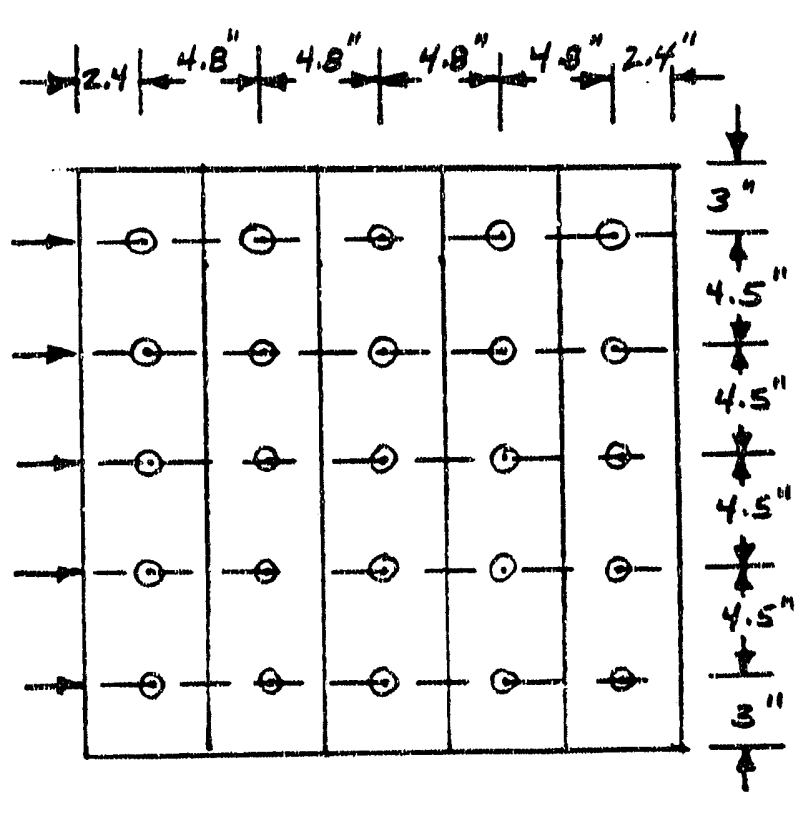

TEST 17

Solid Lines : Diffuser Baffles

Dotted Lines: $\quad$ Pipe Center Lines

: : $\mathrm{NH}_{3}$ Nozzle Location 


\section{Figure 5-2}

HISTOGRAM OF VELOCITY DATA AT THE DUMMY CORE OUTLET FOR REACTOR INLET MODEL DESIGN NO. 1

Test 17 Data at Location 4 - Figuie 3-25

Geometry

- Figures $3-1,3-2$, and 3-3

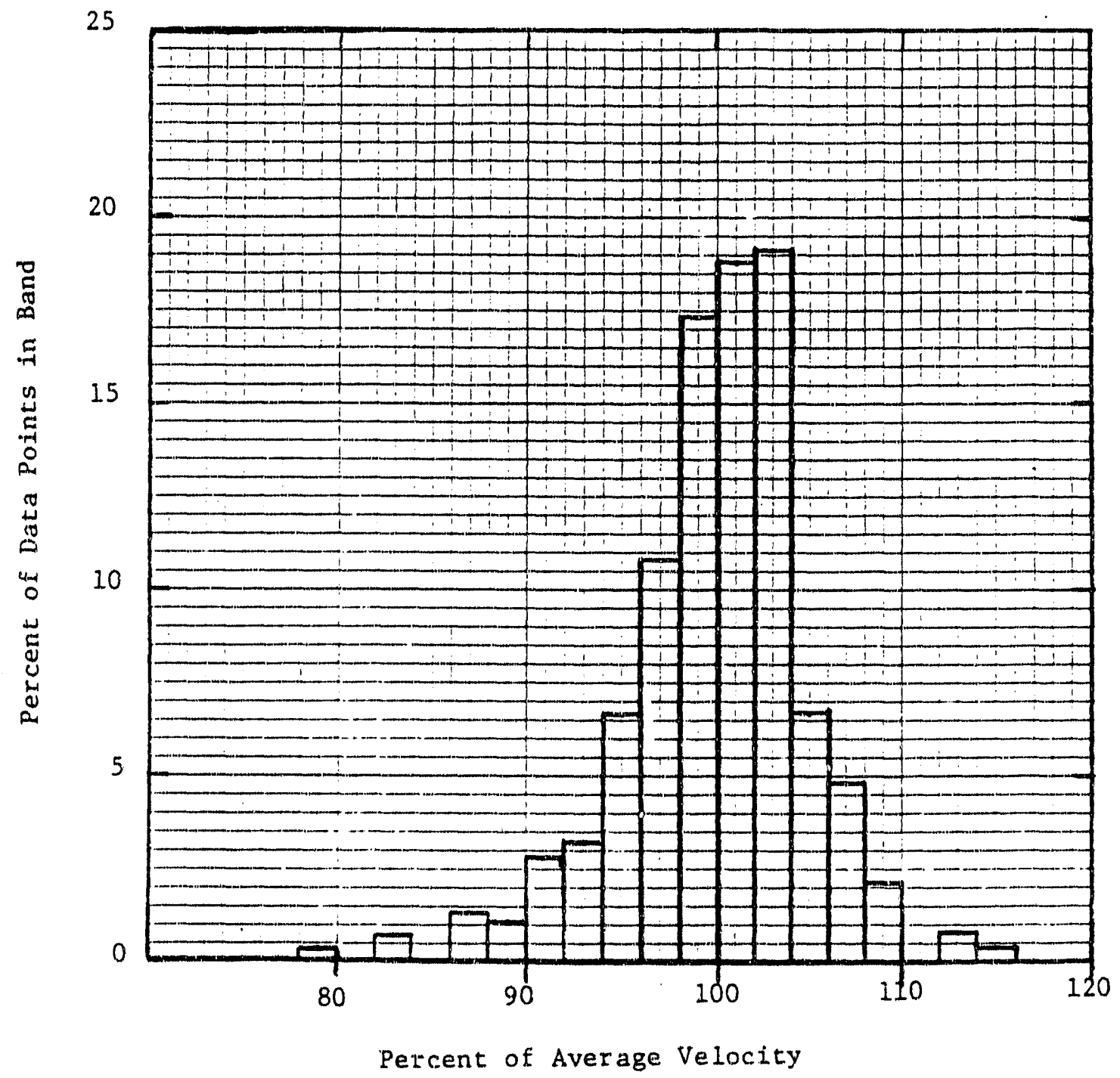


APPENDIX B

Air Heater Specifications/Performance 


\section{Ljungstrum Air Heater Performance}

Air heater manufacturer

Air heater size/type

Number of element sectors
C-E Air Preheater

Size 9/VI (vertical, gas flow down)

12

(Trisector)

Selection 1

(Bisector)

Selection?

Flows (1b/hr):
Air Entering
23,850
27,757
Air Leaving
18,250
22,357
Gas Entering
24,934
24,934
Gas Leaving
30,534
30,334
Temperatures $\left({ }^{\circ} \mathrm{F}\right)$ :
Air Entering
100
100
Air Leaving
633
579
Gas Entering
700
700
Gas Leaving Uncorr.
334
298
Gas Leaving Corr.
293
264

Pressure Differentials (in. $\mathrm{H}_{2} \mathrm{O}$ ):

Air-side Pressure Drop

1.60

1.80

Gas-side Pressure Drop

2.85

2.50

Hot-end Differential

1.00

1.00

Cold-end Differential

5.45

5.30 
Rotary Air Heater Rotor Designs

Selection 1:

Layer

Hot End

cold End
Depth

$30 "$

$42 "$

Selection 2:
Layer

Hot End

Intermediate

Cold End
Depth

$18 "$

$42^{\prime \prime}$

$12 "$
Desian

DU

NF-3.5

\section{Material}

Low alloy corrosion resistant steel Low alloy corrosion resistant steel

\section{Material}

Low alloy corrosion resistant steel Low alloy corrosion resistant steel

Low alloy corrosion resistant steel 


\section{Specifications/Performance of Heat Pipe Heat Exchanger}

Design:

Total Number of Heat Pipes

328

Pipe o.d. (in.)

2.0

Fin Density (fins per inch)

3.0 gas $/ 3.0$ air

Fin Type

Solid

Tube Arrangement

Transverse Pitch (in.)

In-Line

Longitudinal Pitch (in.)

3.75

Total Gas-side Surface Area (sq. ft.)

3.75

Total Air-side Surface Area (sq. ft.)

10,057

4,076

Total Unit Approximate Weight (1b.)

54,100 with transitions

Performance:

Flue Gas

Flow Rate (1b/hr)

Entering Temp. ( $\mathrm{F}$ )

Leaving Temp. ("F)

Pressure Drop (in. $\mathrm{H}_{2} \mathrm{O}$ )

Avg. Specific Heat (Btu/16 ${ }^{\circ} \mathrm{F}$ )

Heat Recovered (MMBtu/hr)

Minimum Metal Temp. ( $\mathrm{F}$ )
24,934

700

300

1.60

0.263

2.69

277
Combustion Air

21,759

100

588

3.00

0.247 


\section{APPENDIX C}

Fans Performance Data 
Hot Air Fan 
6.5 Hot Alr Fan (Reinjection to unit)

6.5.1 General

\subsubsection{Fan typo (modaleries)}

\subsubsection{Type contral}

\subsubsection{Drive arrangament}

\subsubsection{Number of fans}

\subsubsection{Pertormance}

6.5.2.1 Pertormance data for each fan at:
a. Spoed - rpm
b. Capacity - actm
c. Density - belcutt
d. Temparenure - deg $F$
o. Prescuros - "wg
1. Inlor static
2. Discharoe static
3. Fan static prossure
1. Static otficioncy - \%
g. Power input to fan - bhp
n. Comprossibility

6.5.2.2 Pertormance data for each lan at:
a. Speed - rpm
b. Capacisy - chim
c. Denaty ant
d. Tompen - deg F

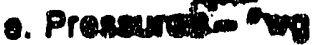
1. Initet ano
2. Dlscharge stadc
3. Fan static prossure
1. Statuc efficiency - 40
g. Power inpus so fen - bnp
n. Comproasibility

\subsubsection{General pertermenco data}
a. Peas horiapower (P TB density)
b. Musimin torius expected $(t-t b)$
C. Starting tarenes $(n-10)$

520000L4N, SWSI, Arr. $\$ 7$

Inlet vane control

Direct conrected

1

Tost Block (Guaranteed)

$\frac{\frac{1775}{37000}}{.037} \frac{\frac{1775}{31784}}{\frac{.037}{600}}$

$\frac{\frac{-5.5}{14.5}}{\frac{20.0}{82.5}} \frac{141}{.983}$

$-4.0$

14.0

18.0

78.2

115

.985

\begin{tabular}{l}
$\begin{array}{l}\text { Design } \\
1775\end{array}$ \\
\hline$\frac{.0097}{600}$ \\
\hline
\end{tabular}

Minimum

1775

$\frac{\frac{1775}{9793}}{.037}$

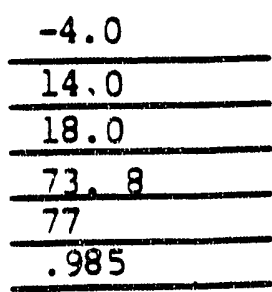

$\frac{\frac{-4.0}{14.0}}{\frac{18.0}{50.4}} \frac{55}{.985}$

175

445 d TB densIt?

Depends on density 
Sinall Reactor Fans 
6.3 Small Reactor Fans (suctorn from cyclonos)

\subsubsection{General}

\subsubsection{Fan type (modayeartes)}

\subsubsection{Type control}

\subsubsection{Drive arrangement}

\subsubsection{Number of fans}

\subsubsection{Pertormenco}

6.3.2.1 Portormanes dor forech fan at:
a. Speed - rpen
b. Capscity - actm
c. Donaity - Poscunt
d. Temperature - dog F
o. Prosaures - "wg
1. Inler atade
2. Discharge static
3. Fan statc pressure
1. Static efficiency - $\%$
g. Power imper to fan - bhp
h. Compressibility

6.3.2.2 Pertormance data for each fan at:
a. Speed - rom
b. Capacity - actm
c. Consity - lbs/cutt
d. Tomperature - deg F
o. Pressures - "wg
1. Iniar static
2. Discharge static
3. Fan statle prescure
- f. Static efficiency - \%
g. Power inpur to fan - bhp
n. Compressibility

6.3.2.3 General performence date
a. Peak horsepower (@ TB density)
b. Maximum torque expected ( $(h-1 b)$
c. Starting torque ( $k-1 b)$

355000Ll, SWSI, Arr. $=7$

Variable Frequency Controller

$\mathrm{V}$ belt

2
Tox Block

(ourantood)

$\frac{2600}{4000} \frac{.0314}{750}$

$-25.5$

$\frac{-8.5}{\frac{-25}{17.0}} \frac{16.3}{14}$

Dexign

1497

2952

.0336

700

$\frac{\frac{-14.25}{-9.0}}{\frac{5.25}{74.9}} \frac{3.25}{1.0}$
Maximum

$\frac{2404}{3683} \frac{.0314}{750}$

$\frac{\frac{-23.87}{-9.0}}{\frac{14.87}{78.2}} \frac{1.1}{1.0}$

Minimum

680

2354

.0365

620

$\frac{\frac{-9.58}{-9.0}}{\frac{0.58}{36}} \frac{}{16}$

24

48 a density

Decends on densiev 
Large Reactor Fans 
6.1 Large Reactor Funs (suction from cyclones)

B.1.1 Goneral

\subsubsection{Fan type (modeticerios)}

540000II, SWSI, ALI. $\$ 7$

6.1.1.2 Type control

Variable Frequency controller

\subsubsection{Drive arrangament}

Direct Connected

\subsubsection{Number of fans}

\subsubsection{Pertormance}

\section{9.2.1 Pertormance date for eech ten at:}
a. Speed - rpm
b. Capacity - actm
c. Density - low/cutt
c. Temperarure o deg $F$
o. Pressures - "wo
1. Inlol atade
2. Dischers
3. Fan are
P. State end

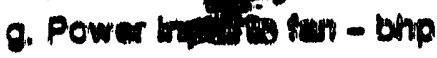
n. Compresendsiny

6.1.2.2 Pertormanco dan lor each fan at:
a. Spaed - rpin
b. Capinewy - com
c. Dondty on becan
d. Tompermeno - deo $F$
- Praceures on "wo
1. Intet atadic
2. Dlechargo static
3. Fan statte presuure
1. Stave atriciency - ac
9. Power input to fan - bho
h. Comprosentidity

Test 8lock

Maximum

(guaranteed)

\begin{tabular}{|c|c|}
\hline 1775 & 1621. \\
\hline$\frac{16000}{.0434}$ & $\frac{14354}{.0434}$ \\
\hline 400 & 400 \\
\hline-34 & 342.1 \\
\hline$\frac{-8}{26.0}$ & $\begin{array}{r}-9.0 \\
23.1 \\
\end{array}$ \\
\hline 79.75 & 85.14 \\
\hline 82 & 61 \\
\hline .976 & .979 \\
\hline
\end{tabular}

\subsubsection{Genoral porformance date}
a. Peax horsepower (P Ta dansity)
b. Maximum torque expected $(t-1 b)$
c. Starting rorque ( $(t-10)$

\begin{tabular}{l} 
Minimum \\
665 \\
\hline 4526 \\
\hline .0551 \\
\hline 250 \\
\hline
\end{tabular}

$\frac{\frac{-18.30}{-9.0}}{\frac{9.3}{78.3}} \frac{18}{1.0}$

$\frac{-14.30}{-9.0} \frac{5.3}{5}$




\section{APPENDIX D}




\section{STANDARD ACTIVITY TEST PARAMETERS}

Per the Evaluation Agreement reached between Southern Company Services (SCS) and each catalyst supplier, catalyst activity data will be measured using laboratory reactor(s) operating under conditions agreed to by SCS and the catalyst supplier. SCS wishes to remove large variations in laboratory activity test procedures of SCR catalysts between the various suppliers. SCS is requesting comment on the testing parameters as listed below. We wish to obtain each supplier's recomnendation for what he considers are the most appropriate test conditions to determine differences in activity (NOx conversion) and selectivity ( $\mathrm{SO} 2$ oxidation) during the course of the 2 year DOE/SCS SCR project. SCS will assess the catalyst suppliers' comments and recommendations and attempt to develop a uniform set of testing conditions.

Eight areas of testing parameters are listed below for review and comment. Within each area additional points/questions are included for clarification. We request that you provide a description of laboratory procedures that address each of the points listed below and a labeled schematic/sketch of the laboratory test apparatus and related equipment (e.g., analytical instruments and feed gas delivery system). Some of the points/concerns under these areas, though, may not necessarily apply to an individual catalyst. If so, please provide explanatory comments. Aiso, if you find that we have left off an important issue, please list and describe separately, and explain why that issue is important.

\section{Testing Parameters}

\section{Catalyst Preparation:}

a. What are the shape and size of catalysts tested in the lab reactor? Is the surface area/volume ratio a critical parameter, and if so, what is the desired value?

b. What is the void volume in the reactor? Is channeling in the lab reactor a concern and how is it addressed?

c. Sample usage for activity and analytical tests. Will catalyst pieces for activity and analytical testing be obtained from the same sampie removed from the pilot reactor?

d. Removal of flyash from catalyst surface Is this necessary or is it better to measure the influence of flyash, e.g. adsorbed ammonium bisulfate?

e. What is the minimum catalyst volume (weight) for accuracy? 


\section{Catalyst Pretreatment (Startup):}

a. What is the gas composition for pretreatment (e.g. SO2, NH3, 02 , NOX, H2O, etc.)?

Is a presulfiding or similar step required, and if so, what are the conditions used?

b. Sequence of addition of gases and duration of exposure to catalyst. Is the reactor bypassed when adjusting gas composition?

c. What is the rate of heatup?

d. What are the initial and final temperatures?

e. Gas flow (total volume passed through reactor) and its relative importance.

f. System pressure.

\section{Reactor Design:}

a. Dual bed reactor, for side by side comparison with same feed, versus single bed measurements of fresh and spent catalyst, and reasoning for preference.

b. What are the internal diameter and length of the reactor?

c. Adiabatic or isothermal operation?

d. Flow regime prior to and following catalyst. How important is it to maintain laminar flow?

e. Location of thermowell(s) and influence on catalyst packing. How many and where are temperature measurements taken? What effect is there on the flow regime?

f. Amount, size, and location of glass wool/glass beads for mixing.

g. External heating jacket How are the reactor and connecting lines heated?

h. Preheaters, if any.

i. Upflow or downflow of reactant gases.

j. Pressure regulators, if any.

4. Measurement Devices:

a. Analytical instruments description with sensitivities and detection limits.

b. Heated lines to prevent condensation of H2SO4, ABS, NH3, etc.?

c. Description of mass flow controllers (or similar device used to measure flow) and their accuracies.

Will the flow over long periods be verified with wet test meter or similar device?

d. How will samples be handled?

5. Feed Gas Preparation:
a. How will feed gas be prepared?
b. If feed gas is premixed, what type of cylinders are to be used?
c. How will adsorption on walls of cylinders be avoided (e.g. for SO3, $\mathrm{NH3}$, etc.)?
d. Will $\mathrm{NH} 3$ and $\mathrm{SO}_{3}$ have to be kept separated? 


\section{Operating Conditions:}
a. Area/space velocity.
b. Temperature.
c. Linear velocity.
d. Ammonia/NOx ratio.
e. NO Tevel.
f. N02 level.
g. SO2 level.
h. S03 level.
i. 02 level.
j. H2O level.
k. N2 level.
1. Impurities. Are there any in the feed that could be of concern and how addressed?
m. How will steaúy state be verified?
$n$. Are there different operating conditions for determining activity and selectivity?
o. Empty reactor tests for $\mathrm{NH}_{3}$ and $\mathrm{SO} 2$ oxidation.
p. Pressure of reactor, permitted pressure drop.

\section{Data Reduction and Analysis:}
a. Continuous or intermittent analys is of inlet/outlet gas compositions and specific analysis frequency?
b. Temperature recorder.
What type will be used; is it continuous?
c. How will side reactions be accounted for?
For instance, ABS, AS, NH4NO3, N2O, S03 formation.
d. Account for relative influences of mass transfer to catalyst surface (through pore structure, etc.) and intrinsic activity.
e. Analysis of catalyst properties before and after test. Is there a need to determine oxidation state or perform XRD, XRF for poisons, BET surface area, PVD?

\section{Reactor Shutdown:}
a. What procedure is recommended?
b. Sequence of gases.
Is there any particular order during shutdown?
c. Temperature reduction.
What is cool down rate; is it important if catalysts are to be analyzed following lab tests?
d. Unloading of reactor. Any specific procedures needed which may influence any tests to
be conducted on catalyst after laboratory activity tests? 

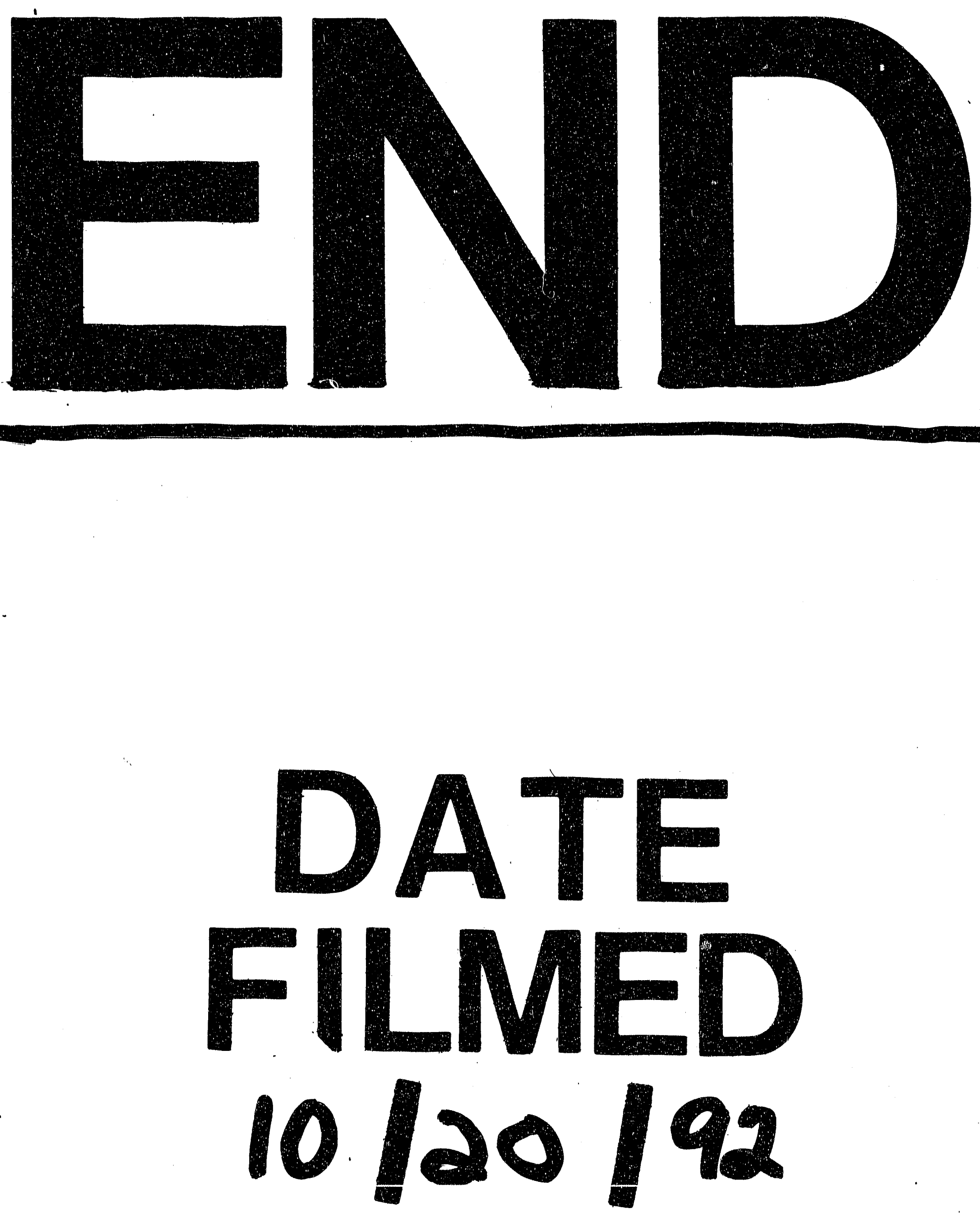

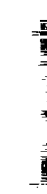


